\title{
Front Matter: Volume 10657
}

, "Front Matter: Volume 10657," Proc. SPIE 10657, Next-Generation Spectroscopic Technologies XI, 1065701 (18 July 2018); doi: 10.1117/12.2502371

Event: SPIE Commercial + Scientific Sensing and Imaging, 2018, Orlando, FL, United States 


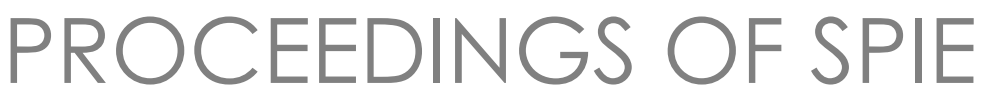

\title{
Next-Generation Spectroscopic Technologies XI
}

\author{
Mark A. Druy \\ Richard A. Crocombe \\ Steven M. Barnett \\ Luisa T.M. Profeta \\ Abul K. Azad \\ Editors
}

16-18 April 2018

Orlando, Florida, United States

Sponsored and Published by

SPIE 
The papers in this volume were part of the technical conference cited on the cover and title page. Papers were selected and subject to review by the editors and conference program committee. Some conference presentations may not be available for publication. Additional papers and presentation recordings may be available online in the SPIE Digital Library at SPIEDigitalLibrary.org.

The papers reflect the work and thoughts of the authors and are published herein as submitted. The publisher is not responsible for the validity of the information or for any outcomes resulting from reliance thereon.

Please use the following format to cite material from these proceedings:

Author(s), "Title of Paper," in Next-Generation Spectroscopic Technologies XI, edited by Mark A. Druy, Richard A. Crocombe, Steven M. Barnett, Luisa T.M. Profeta, Abul K. Azad, Proceedings of SPIE Vol. 10657 (SPIE, Bellingham, WA, 2018) Seven-digit Article CID Number.

ISSN: 0277-786X

ISSN: 1996-756X (electronic)

ISBN: 9781510618251

ISBN: 9781510618268 (electronic)

Published by

SPIE

P.O. Box 10, Bellingham, Washington 98227-0010 USA

Telephone +1 3606763290 (Pacific Time) · Fax +1 3606471445

SPIE.org

Copyright (C) 2018, Society of Photo-Optical Instrumentation Engineers.

Copying of material in this book for internal or personal use, or for the internal or personal use of specific clients, beyond the fair use provisions granted by the U.S. Copyright Law is authorized by SPIE subject to payment of copying fees. The Transactional Reporting Service base fee for this volume is $\$ 18.00$ per article (or portion thereof), which should be paid directly to the Copyright Clearance Center (CCC), 222 Rosewood Drive, Danvers, MA 01923. Payment may also be made electronically through CCC Online at copyright.com. Other copying for republication, resale, advertising or promotion, or any form of systematic or multiple reproduction of any material in this book is prohibited except with permission in writing from the publisher. The CCC fee code is 0277 $786 \mathrm{X} / 18 / \$ 18.00$.

Printed in the United States of America.

Publication of record for individual papers is online in the SPIE Digital Library.

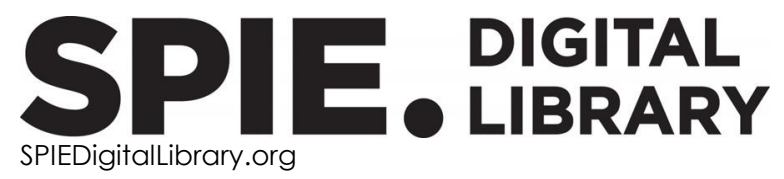

Paper Numbering: Proceedings of SPIE follow an e-First publication model. A unique citation identifier (CID) number is assigned to each article at the time of publication. Utilization of CIDs allows articles to be fully citable as soon as they are published online, and connects the same identifier to all online and print versions of the publication. SPIE uses a seven-digit CID article numbering system structured as follows:

- The first five digits correspond to the SPIE volume number.

- The last two digits indicate publication order within the volume using a Base 36 numbering system employing both numerals and letters. These two-number sets start with 00, 01, 02, 03, 04, 05, 06, 07, 08, 09, OA, OB ... 0Z, followed by 10-1Z, 20-2Z, etc. The CID Number appears on each page of the manuscript. 


\title{
Contents
}

\author{
vii $\quad$ Authors \\ ix Conference Committee \\ xi Introduction
}

\section{SMARTPHONE SPECTROSCOPY}

1065702 Smartphone spectroscopy for mobile health diagnostics with laboratory-equivalent capabilities (Invited Paper) [10657-1]

1065703 Fast Fourier Transform of non-periodic signals generated from a microplasma: migrating from a desktop computer to an loT-connected smartphone [10657-2]

1065704 From portable Raman to mobile Raman: the progression of Raman spectroscopy [10657-3]

1065705 The Internet of Things (IOT) for a smartphone-enabled optical spectrometer and its use on-site and (potentially) for Industry 4.0 (Invited Paper) [10657-4]

1065706 Progress towards low resolution visible spectrometry with COTS components (Invited Paper) [10657-5]

\section{LASER SOURCES AND SPECTROSCOPY}

1065707 Tunability improvement of a doubly resonant OPO for fast and high resolution gas spectroscopy (Invited Paper) [10657-6]

1065708 A new way of controlling NesCOPOs (Nested Cavity doubly resonant OPO) for faster and more efficient high resolution spectrum measurement (Invited Paper) [10657-7]

10657 OA Integrated multi-wavelength mid-IR light source for gas sensing [10657-9]

\section{NEW TECHNOLOGIES}

10657 OB Advances in miniaturized spectral sensors [10657-10]

10657 OE Low cost rapid fabrication of vertical LVOF microspectrometer on-chip for MIR sensing [10657-13] 
10657 OF An analytic method for spectrum recovery from wedge or staircase spectrometers [10657-14]

10657 OG Compact snapshot image mapping spectrometer (SNAP-IMS) for hyperspectral data cube acquisition using unmanned aerial vehicle (UAV) environmental imaging [10657-28]

\section{LIBS AND OPTICAL EMISSION}

$10657 \mathrm{OH} \quad$ A vaporization chamber for micro- or nano-sample introduction into a battery-operated microplasma: from rapid prototyping via 3D printing to Computational Fluid Dynamics (CFD) simulations [10657-15]

\section{RAMAN SPECTROSCOPY AND IMAGING}

10657 OK Raman-based point and proximal detection and imaging (Invited Paper) [10657-18]

10657 OM Chemical, biological, and trace gas detection and measurement with a newly developed integrating Cavity Enhanced Raman (iCERS) technique [10657-20]

10657 ON High resolution handheld Raman and reflectance hyperspectral imaging for remote sensing and threat detection (Invited Paper) [10657-21]

\section{NANOSCALE IMAGING}

$1065700 \quad$ Infrared spectroscopy below the diffraction limit using an optical probe (Invited Paper) [10657-22]

NOVEL IMAGING INSTRUMENTS

10657 OR A speckle-based approach to compressive hyperspectral imaging [10657-25]

10657 OT Novel use of shortwave infrared hyperspectral imaging for standoff detection of explosives and narcotics in room clearing applications [10657-27]

10657 OU Real-time, short-wave, infrared hyperspectral conforming imaging sensor for the detection of threat materials [10657-29]

TERAHERTZ I

10657 OW Terahertz atmospheric propagation studies in support of wireless remote sensing (Invited Paper) [10657-31]

iv 
10657 OY A new THz technology: artificial dielectrics (Invited Paper) [10657-33]

$106570 Z$ Quadrupolar interactions to achieve high Q plasmon induced transparency (Invited Paper) [10657-34]

TERAHERTZ III

1065714 Low temperature dielectric properties of ammonium nitrate in terahertz regime (Invited Paper) [10657-39] 
Proc. of SPIE Vol. 10657 1065701-6

Downloaded From: https://www.spiedigitallibrary.org/conference-proceedings-of-spie on 26 Apr 2023 Terms of Use: https://www.spiedigitallibrary.org/terms-of-use 


\section{Authors}

Numbers in the index correspond to the last two digits of the seven-digit citation identifier (CID) article numbering system used in Proceedings of SPIE. The first five digits reflect the volume number. Base 36 numbering is employed for the last two digits and indicates the order of articles within the volume. Numbers start with 00, 01, 02, 03, 04, 05, 06, 07, 08, 09, OA, OB...0Z, followed by 10-1Z, 20-2Z, etc.

Achanta, Venu Gopal, $0 Z$

Agarwal, G. S., $0 Z$

Alajoki, Teemu, OA

Alexander, David, OG

Al-Mulla, S., 02

Amoroso, Jan, OB

Azad, Abul K., 14

Bar, llana, OK

Borgen, Lars, OA

Bradley, Rick, OB

Buczyński, Ryszard, OA

Carlson, J., 02

Carron, Keith T., 04

Chen, Nan, OE

Cherchi, Matteo, OA

Chuan, Kailiang, $\mathrm{OE}$

Colin, Alexis, 07

Cunningham, B. T., 02

Dallesasse, J. M., 02

DePrenger, Michael J., OF

Deshmukh, Prathmesh, $\mathrm{OZ}$

Deutsch, Erik R., ON

Duttagupta, S. P., OZ

Dwight, Jason G., OG

Ernst, Henrik, OE

Favela, Kristin A., OM

Fitzgerald, Ryan, 03, 05, OH

French, Rebecca, OR

Fry, Edward S., OM

Furstenberg, Robert, 00

Georges des Aulnois, Johann, 07, 08

Gigan, Sylvain, OR

Goh, Simon Chun Kiat, OE

Gomer, Nathaniel R., OT

Grimieau, Axel, 08

Grischkowsky, Daniel R., OW

Guina, Mircea, OA

Hajian, Arsen R., ON

Harjanne, Mikko, OA

Hebert, Martial, OU

Heinilehto, Noora, OA

Houck, Alexandra, $\mathrm{OB}$

Houck, William, OB

Hruska, Curtis, OB

Hsiung, Chang, $\mathrm{OB}$

Huehnerhoff, Joseph, ON

Huffman, T. J., 00

Jedlovec, Gary J., OG

Kalinowski, Przemyslaw, OA
Karanassios, Vassili, 03, 05, OH

Karioja, Pentti, OA

Kasztelanic, Rafał, OA

Kendziora, Christopher A., 00

Kesler, B., 02

Klimek, Michael, OB

Kluczyński, Paweł, OA

Lee, Chengkuo, OE

Long, K. D., 02

Lozo, Jason A., ON

Luvall, Jeffrey C., OG

Martin, David, OB

Mason, John D., OM

McGill, R. A., 00

Mendis, Rajind, OY

Meysing, Daniel, OB

Miller, Christopher W., OF

Moon, Denise E., OT

Moore, David S., 14

Moore, Thomas Z., OM

Muskens, Otto L., OR

Narasimhan, Srinivasa, OU

Nelson, Matthew P., OT, OU

Nodurft, Dawson T., OM

O'Hara, John F., OW

Ollila, Jyrki, OA

Pawlowski, Michal E., OG

Pires, Bernardo, OU

Prabhu, S. S., $0 Z$

Rahman, Abdur, 14

Rana, Goutam, $\mathrm{OZ}$

Ratajczyk, Marcin, OA

Ray, Bryan H., 04

Salo, Tomi, OA

Saxe, Steve, OB

Scheeline, Alexander, 06

Shiau, Li Lynn, OE

Sillard, Léo, 08

Smith, Valton, $\mathrm{OB}$

Su, P., 02

Sun, Lan, $\mathrm{OB}$

Suomalainen, Soile, OA

Szymanski, Benjamin, 07, 08

Tan, Chuan Seng, OE

Tatum, Paul F., OG

Tay, Beng Kang, OE

Tazik, Shawna K., OT, OU

Tedford, Vincent, OM

Tkaczyk, Tomasz S., OG 
Treado, Patrick J., OU

Tuorila, Heidi, OA

Viheriälä, Jukka, OA

Virtanen, Sami, OA

Von Gunten, Marc, OB

Wan, Y., 02

Wang, Emily, 03

Wang, Shurui, OE

Wierszewski, Jason G., OT

Woodburn, E., 02

Yakovlev, Vladislav V., OM

Yetzbacher, Michael K., OF

Zhi, Tiancheng, OU

Zia, Nouman, OA 


\title{
Conference Committee
}

\author{
Symposium Chair \\ Robert Fiete, Harris Corporation (United States) \\ Symposium Co-chair
}

Jay Kumler, JENOPTIK Optical Systems, LLC (United States)

Conference Chairs

Mark A. Druy, Galvanic Applied Sciences USA Inc. (United States)

Richard A. Crocombe, Crocombe Spectroscopic Consulting, LLC (United States)

Steven M. Barnett, Barnett Technical Services, LLC (United States)

Luisa T.M. Profeta, Field Forensics, Inc. (United States)

Abul K. Azad, Los Alamos National Laboratory (United States)

Conference Program Committee

Leigh J. Bromley, DRS Daylight Solutions (United States)

John M. Dell, The University of Western Australia (Australia)

Jason M. Eichenholz, Open Photonics, Inc. (United States)

Fredrick G. Haibach, Confluent Sciences Consulting, Inc. (United States)

Willem Hoving, Anteryon BV (Netherlands)

Vassili Karanassios, University of Waterloo (Canada)

Martin Kraft, Carinthian Tech Research AG (Austria)

Jouko O. Malinen, VTT Technical Research Center of Finland (Finland)

Ellen V. Miseo, Hamamatsu Corporation (United States)

Jeffry J. Santman, Corning Advanced Optics (United States)

David W. Schiering, CziTek, LLC (United States)

John Seelenbinder, Agilent Technologies (United States)

Ulrike Willer, Technische Universität Clausthal (Germany)

\section{Session Chairs}

1 Smartphone Spectroscopy

Richard A. Crocombe, Crocombe Spectroscopic Consulting, LLC (United States)

2 Laser Sources and Spectroscopy

Luisa T.M. Profeta, Field Forensics, Inc. (United States) 
3 New Technologies

Steven M. Barnett, Barnett Technical Services, LLC (United States)

$4 \quad$ LIBS and Optical Emission

Steven M. Barnett, Barnett Technical Services, LLC (United States)

5 Raman Spectroscopy and Imaging

Luisa T.M. Profeta, Field Forensics, Inc. (United States)

$6 \quad$ Nanoscale Imaging

Richard A. Crocombe, Crocombe Spectroscopic Consulting, LLC (United States)

$7 \quad$ Novel Imaging Instruments

Luisa T.M. Profeta, Field Forensics, Inc. (United States)

8 Terahertz I

Abul K. Azad, Los Alamos National Laboratory (United States)

9 Terahertz II

Abul K. Azad, Los Alamos National Laboratory (United States)

10 Terahertz III

Abul K. Azad, Los Alamos National Laboratory (United States) 


\section{Introduction}

The past twenty-five years have seen a massive investment in photonics, electronics, and MEMS aimed at developing new telecommunications capabilities and innovative consumer products. This has led to advances in miniature optics, light sources, tunable filters, array detectors, fiber optic sensors, and a range of other photonic devices across the whole electromagnetic spectrum, along with technologies for their mass production. Similarly, in recent years, there have been remarkable developments in handheld consumer electronics, especially mobile devices ("smartphones"). Today's devices contain advances in RF technology, processors, displays, operating systems, user interfaces, memory, Bluetooth, WiFi, GPS, cameras, accelerometers, etc. These technologies are increasingly being exploited in new spectroscopic instruments, and are now the base of nextgeneration handheld scientific instruments.

Portable and handheld instruments tend to be more targeted at specific applications than their laboratory predecessors. They may have performance (measured as resolution, spectroscopic range, signal-to-noise, etc.) that is 'good enough' for field screening applications. However, they are often more selective, smaller, cheaper, more robust, and designed to give these actionable answers to non-scientist operators in the field. Spectroscopy-based systems are now making critical judgments in environments and applications that were unreachable twenty years ago, from hazardous materials to the operating theater, and from field geologists to customs and border personnel.

Advances in array detectors (CCD, CID, InGaAs, InSb, SLS, MCT, CMOS, etc.), with compact wavelength-selection devices (LVFs, mosaics, Fabry-Perots), are enabling a new generation of faster imaging spectrometers with both laboratory and field applications. Lower-cost microbolometer infrared arrays have been developed, employing MEMS techniques. New laser-based sources (quantum cascade lasers, interband cascade lasers, supercontinuums, terahertz, etc.), particularly in the mid-infrared, are being used in combination with advances in detector technology to create new spectroscopic platforms. Novel designs also enable very compact spectrometers and imagers, suitable for use on airborne platforms, including drones, and now we have the first generation of handheld hyperspectral imagers. The latest developments have driven the cost of hyperspectral imagers in the silicon detector region down dramatically, and are looking towards incorporating them in smartphones. The concurrent improvements in analytical theory, data analysis methods, algorithms, and the power of portable processors enable instrument designers to 'put a PhD scientist in the box' and empower field spectroscopic devices to give specific actionable answers. 
This conference focused on advanced technologies for spectroscopic instrumentation, particularly the ultraviolet-visible, infrared, near-infrared, terahertz and Raman molecular techniques, but also included advances enabling miniature and portable spectrometers across the electromagnetic spectrum. Another critical topic area discussed was materials development relevant to shrinking the physical sizes of technologies enabling these applications. The 2017 and 2018 conferences both included special sessions on terahertz technologies and applications.

This conference premiered at Optics East 2007 in Boston, MA (United States), and has been part of the DCS Meeting for many years now. The conference is now rotating between three sites, Baltimore, MD; Anaheim, CA; and Orlando, FL; with the 2018 conference being in Orlando. It spanned two-and-a-half days, and was divided into sessions focusing on: Smartphone spectroscopy; Laser Sources and Spectroscopy; New Technologies; LIBS and Optical Emission Raman Spectroscopy and Imaging; Nanoscale Imaging, Novel Imaging Instruments; Terahertz Technologies and Applications. The Conference Chairs believe that this Conference in 2015 had the first SPIE session devoted to "Smartphone Spectroscopy", and we anticipate that this will be a continuing and growing part of this Conference. In all, 37 papers were presented, 26 of which are included in this volume.

\section{Mark A. Druy Richard A. Crocombe Steven M. Barnett Luisa T. M. Profeta Abul K. Azad}

